\title{
Review on Optimization of Drinking Water Treatment Process
}

\author{
Mohamed Farhaoui1,2, Mustapha Derraz ${ }^{2}$ \\ ${ }^{1}$ National Office of Electricity and Drinking Water, Meknes, Morocco \\ ${ }^{2}$ Biology Department, University of Moulay Ismail, Meknes, Morocco \\ Email: farhaouimed@gmail.com,mfarhaoui@onee.ma, mderraz@ymail.com
}

Received 26 April 2016; accepted 27 June 2016; published 30 June 2016

Copyright (C) 2016 by authors and Scientific Research Publishing Inc.

This work is licensed under the Creative Commons Attribution International License (CC BY). http://creativecommons.org/licenses/by/4.0/

(c) (i) Open Access

\begin{abstract}
In the drinking water treatment processes, the optimization of the treatment is an issue of particular concern. In general, the process consists of many units as settling, coagulation, flocculation, sedimentation, filtration and disinfection. The optimization of the process consists of some measures to decrease the managing and monitoring expenses and improve the quality of the produced water. The objective of this study is to provide water treatment operators with methods and practices that enable to attain the most effective use of the facility and in consequence optimize the cubic meter price of the treated water. This paper proposes a review on optimization of drinking water treatment process by analyzing all of the water treatment units and gives some solutions in order to maximize the water treatment performances without compromising the water quality standards. Some practical solutions and methods are performed in the water treatment plant located in the middle of Morocco (Meknes).
\end{abstract}

\section{Keywords}

Optimization, Coagulation Process, Turbidity Removal, Water Treatment

\section{Introduction}

The demand on water supply is increasing over the last century due to improved lifestyle, industrial development and population growth. This increased demand is facing a paradox to produce treated water with high quality at lower cost. In order to reduce the water cost, it is very important to optimize the operating expenses in the water treatment plant (power, chemicals, operator's expenses...) and many measures should be performed in this vision.

The optimization of water treatment plant is not a disciplinary to maximize the treatment objective and mi- 
nimize the cost of the water produced. But it consists of understanding the functioning of the treatment plant and treasure the experience of the operators in dealing with all treatment process related to different aspects.

This paper addresses the problem of optimizing of the conventional drinking water plant and proposes some practical to reach this goal. This paper is organized as fellows. After an introduction of the objective of this study, the water treatment operation is described in Section 2. Review on optimization of conventional drinking water treatment plant is discussed in Section 3. In Section 4, some practical methods are explained.

\section{Water Treatment Operation}

Meknes region is located in the middle of Moroccan Kingdom, has a Mediterranean climate with continental influences. The temperature shifts from cool and cold in winter to hot days in the summer months of June - September. The agriculture and industry are the mean activities in the region.

This study was developed in a water treatment plant located in Meknes, whose source is two big springs Bittit $(630 \mathrm{l} / \mathrm{s})$ and Ribaa $(400 \mathrm{l} / \mathrm{s})$. The quality of water, produced by the spring, changes according to the rainfall in the region. Sometimes, it can be affected by the snow in the Atlas Mountains. The treatment water plant, as part of other water resources, water to more than 700,000 inhabitants of Meknes city, and it has a nominal capacity of $600 \mathrm{l} / \mathrm{s}$ of treated water. This water treatment plant is chosen regarding to the variation of the raw water turbidity and because of the availability of data. Figure 1 presents a schematic overview of the various operations necessary to treat the water.

Many measurements of variables recorded by streaming current detectors such as: turbidity level, PH, conductivity, temperature is needed to carry out the jars test in order to determine the optimal dose of the aluminum sulfate. Table 1 shows the raw water variables used in this study, and they present the following variation intervals.

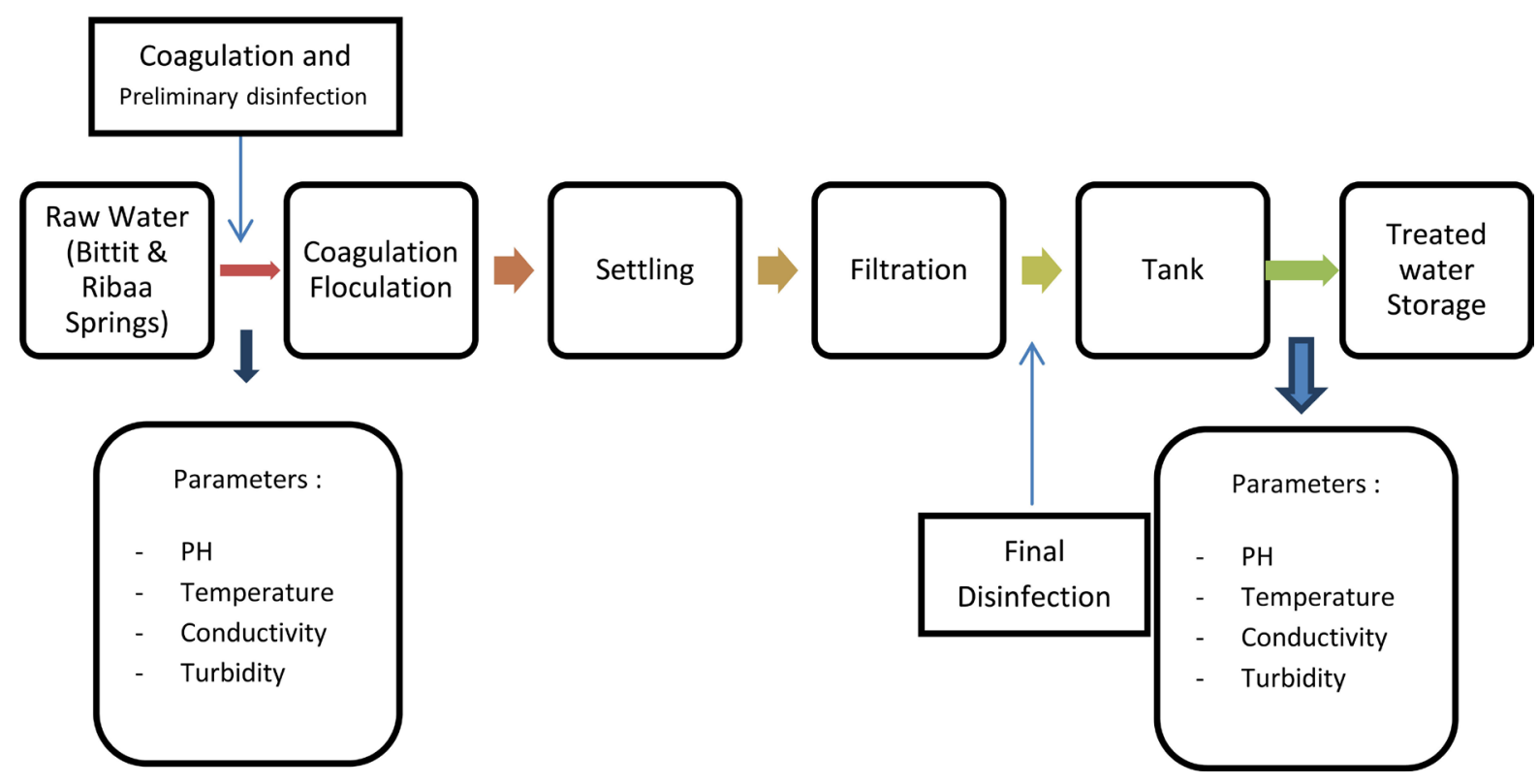

Figure 1. Simplified synopsis of the water treatment plant.

Table 1. Statistical summary of raw water conditions from 01/01/2013 to 31/12/2015 (ONEE, 2015).

\begin{tabular}{ccc} 
Variables & Min & Max \\
\hline Turbidity: Bittit (NTU) & 1.7 & 850 \\
Turbidity: Ribaa (NTU) & 1.62 & 960 \\
PH & 6.80 & 7.74 \\
Temperature: $\left({ }^{\circ} \mathrm{C}\right)$ & 14 & 24.70 \\
Conductivity micro s/cm & 509 & 624 \\
\hline
\end{tabular}


The variation of $\mathrm{PH}$, conductivity and temperature from $01 / 01 / 2013$ to $31 / 12 / 2015$ is given by Figures 2(a)-(c).

In the rainfall period, the turbidity of raw water changes from time to time as shown in the graph below, the turbidity of the raw water can increase to reach levels more than 500 NTU as shown in Figure 3.

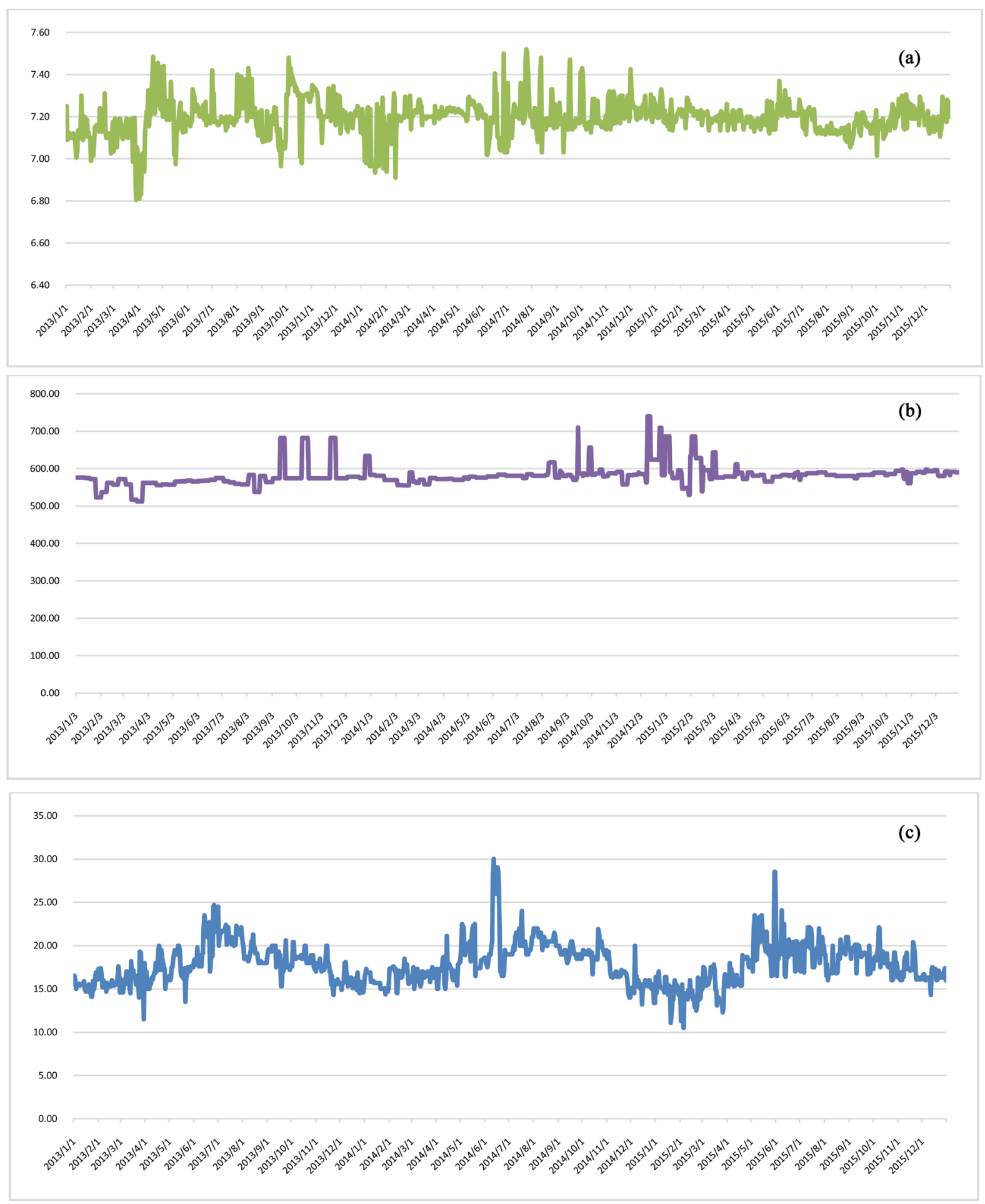

Figures 2. Evolution of PH. (a) conductivity in micro S/cm; (b) and temperature in ${ }^{\circ} \mathrm{C}$; (c) of raw water from 01/01/2013 to $31 / 12 / 2015$. 


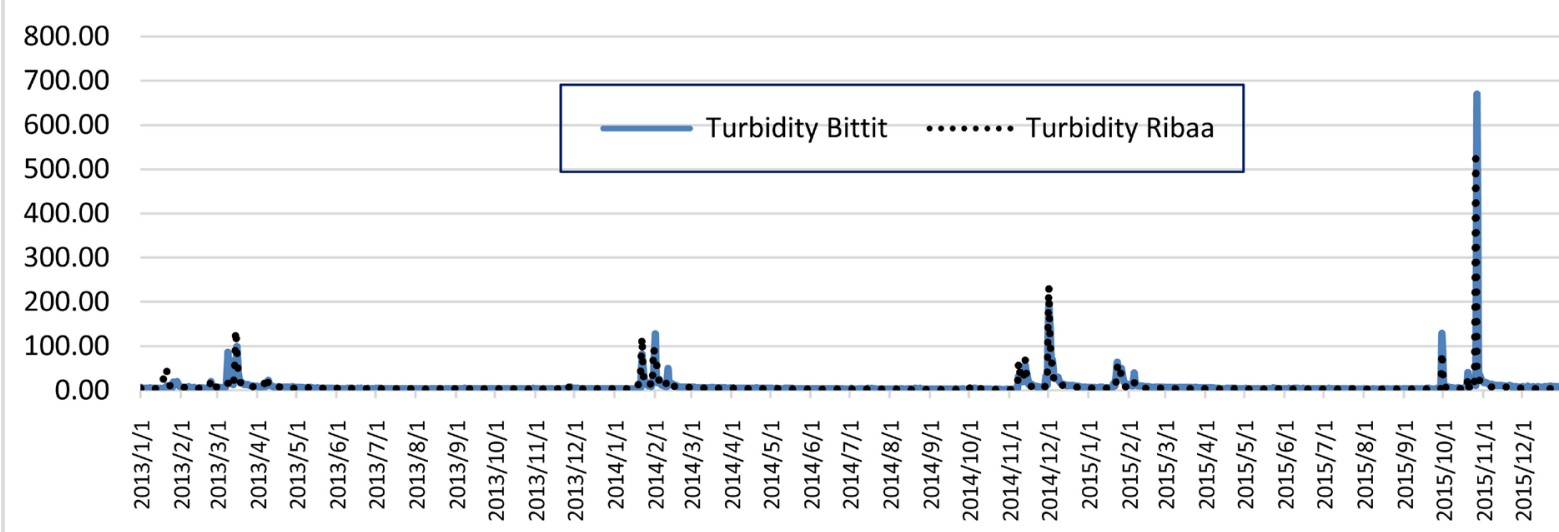

Figure 3. Statistical data of turbidity level of the spring's water from 01/01/2013 to 31/12/2015 (ONEE, 2015).

Table 2. Turbidity levels distribution from 2009 to 2015 (number of days per turbidity level).

\begin{tabular}{|c|c|c|c|c|c|c|}
\hline \multirow[b]{2}{*}{ Year } & \multicolumn{5}{|c|}{ Number of days } & \multirow[b]{2}{*}{ Total } \\
\hline & $\begin{array}{l}\text { Turbidity less or } \\
\text { equal than } 5 \mathrm{NTU}\end{array}$ & $\begin{array}{l}\text { Turbidity more than } \\
5 \text { and less or equal } \\
\text { than } 10 \mathrm{NTU}\end{array}$ & $\begin{array}{c}\text { Turbidity more than } \\
10 \text { and less or } \\
\text { equal than } 20 \text { NTU }\end{array}$ & $\begin{array}{l}\text { Turbidity more than } \\
20 \text { and less or } \\
\text { equal than } 40 \text { NTU }\end{array}$ & $\begin{array}{l}\text { Turbidity more } \\
\text { than } 40 \text { NTU }\end{array}$ & \\
\hline 2009 & 147 & 60 & 101 & 34 & 23 & 365 \\
\hline 2010 & 0 & 0 & 113 & 148 & 104 & 365 \\
\hline 2011 & 0 & 132 & 144 & 59 & 30 & 365 \\
\hline 2012 & 301 & 38 & 17 & 5 & 5 & 366 \\
\hline 2013 & 260 & 74 & 23 & 8 & 0 & 365 \\
\hline 2014 & 247 & 62 & 32 & 20 & 4 & 365 \\
\hline 2015 & 184 & 132 & 34 & 10 & 5 & 365 \\
\hline Total & 1139 & 498 & 464 & 284 & 171 & 2556 \\
\hline Aggregated data & 1139 & 1637 & 2101 & 2385 & 2556 & \\
\hline Percentage & $45 \%$ & $19 \%$ & $18 \%$ & $11 \%$ & $7 \%$ & \\
\hline $\begin{array}{l}\text { Percentage of } \\
\text { Aggregated data }\end{array}$ & $45 \%$ & $64 \%$ & $82 \%$ & $93 \%$ & $100 \%$ & \\
\hline
\end{tabular}

However, the turbidity level is less than 10 NTU this three last years $(2013,2014$ and 2015) for more than $88 \%$ of the year and more than $64 \%$ of the year (1637/2556 days); the turbidity is less than 10 NTU for the six last years as shown by Table 2 .

Table 3 gives the max and min of raw water turbidity by month from 2013 to 2015 .

The chemicals used in the water treatment process consume about 50\% the total operating expenses of the water treatment. The energy cost is between $10 \%$ and $15 \%$ related to the total cost in 2013, 2014 and 2015 . Figure 4 gives the operations expenses of the water treatment plant in the three last years.

In addition, used as coagulant, the aluminum sulfate (SA) consumption is more than $65 \%$ of the total chemicals consumption in the water treatment plant. Le polyelectrolyte (Poly) consumption is less than $10 \%$ and the chlorine is between $16 \%$ and $26 \%$ of the total chemicals used in the water treatment plant according to the water quality as shown by Figure 5 .

\section{Review on Optimization of Drinking Water Treatment Plant}

In order to remove turbidity and contaminants from raw water, the treatment comprises many steps as the settling, aeration, coagulation, sedimentation, filtration and disinfection. The optimization of water treatment plant 
Table 3. Statistical data of turbidity min and max (NTU) measured in 2013, 2014 and 2015 per month (ONEE, 2015).

\begin{tabular}{|c|c|c|c|c|}
\hline \multicolumn{5}{|l|}{ Year: 2013} \\
\hline & \multicolumn{2}{|c|}{ Bittit Spring } & \multicolumn{2}{|c|}{ Ribaa Spring } \\
\hline Month & $\min$ & $\max$ & $\min$ & $\max$ \\
\hline January & 3.70 & 18.95 & 10.00 & 50.00 \\
\hline February & 4.50 & 19.00 & 3.95 & 20.65 \\
\hline March & 4.95 & 98.40 & 4.50 & 136.66 \\
\hline April & 6.40 & 21.95 & 4.90 & 32.77 \\
\hline May & 3.93 & 6.30 & 3.80 & 5.30 \\
\hline June & 3.72 & 4.40 & 3.34 & 4.89 \\
\hline July & 3.30 & 4.33 & 2.92 & 3.62 \\
\hline August & 3.00 & 3.80 & 2.70 & 3.46 \\
\hline September & 3.10 & 4.64 & 2.68 & 4.15 \\
\hline October & 2.90 & 3.99 & 2.46 & 3.62 \\
\hline November & 2.70 & 7.44 & 2.90 & 10.00 \\
\hline December & 3.07 & 4.23 & 2.60 & 3.95 \\
\hline \multicolumn{5}{|l|}{ Year: 2014} \\
\hline & \multicolumn{2}{|c|}{ Bittit Spring } & \multicolumn{2}{|c|}{ Ribaa Spring } \\
\hline & $\min$ & $\max$ & $\min$ & $\max$ \\
\hline January & 3.06 & 81.69 & 3.00 & 120.66 \\
\hline February & 6.48 & 128.00 & 5.93 & 78.90 \\
\hline March & 4.86 & 6.91 & 3.90 & 5.65 \\
\hline April & 4.30 & 4.90 & 3.30 & 4.19 \\
\hline May & 3.17 & 4.77 & 2,48 & 3.37 \\
\hline June & 3.00 & 3.86 & 2.60 & 2.87 \\
\hline July & 2.36 & 4.50 & 2.16 & 2.49 \\
\hline August & 1.74 & 4.20 & 1.88 & 2.28 \\
\hline September & 1.80 & 3.50 & 1.64 & 1.90 \\
\hline October & 1.89 & 4.20 & 1.67 & 11.64 \\
\hline November & 1.80 & 55.50 & 1.68 & 69.29 \\
\hline December & 6.57 & 197.50 & 5.06 & 235.89 \\
\hline \multicolumn{5}{|l|}{ Year: 2015} \\
\hline & \multicolumn{2}{|c|}{ Bittit Spring } & \multicolumn{2}{|c|}{ Ribaa Spring } \\
\hline & $\min$ & $\max$ & $\min$ & $\max$ \\
\hline January & 5.09 & 63.10 & 3.96 & 61.59 \\
\hline February & 6.33 & 38.52 & 3.98 & 19.45 \\
\hline March & 4.97 & 6.27 & 3.26 & 4.64 \\
\hline April & 3.65 & 5.60 & 2.80 & 3.76 \\
\hline May & 3.50 & 5.23 & 2.68 & 3.06 \\
\hline June & 3.40 & 4.52 & 2.61 & 3.19 \\
\hline July & 2.80 & 4.75 & 2.40 & 3.60 \\
\hline August & 2.60 & 3.26 & 2.45 & 2.74 \\
\hline September & 2.70 & 128.45 & 2.35 & 86.63 \\
\hline October & 4.35 & 669.71 & 3.22 & 524.03 \\
\hline November & 6.76 & 17.18 & 3.99 & 13.19 \\
\hline December & 7.18 & 9.54 & 3.42 & 4.02 \\
\hline
\end{tabular}




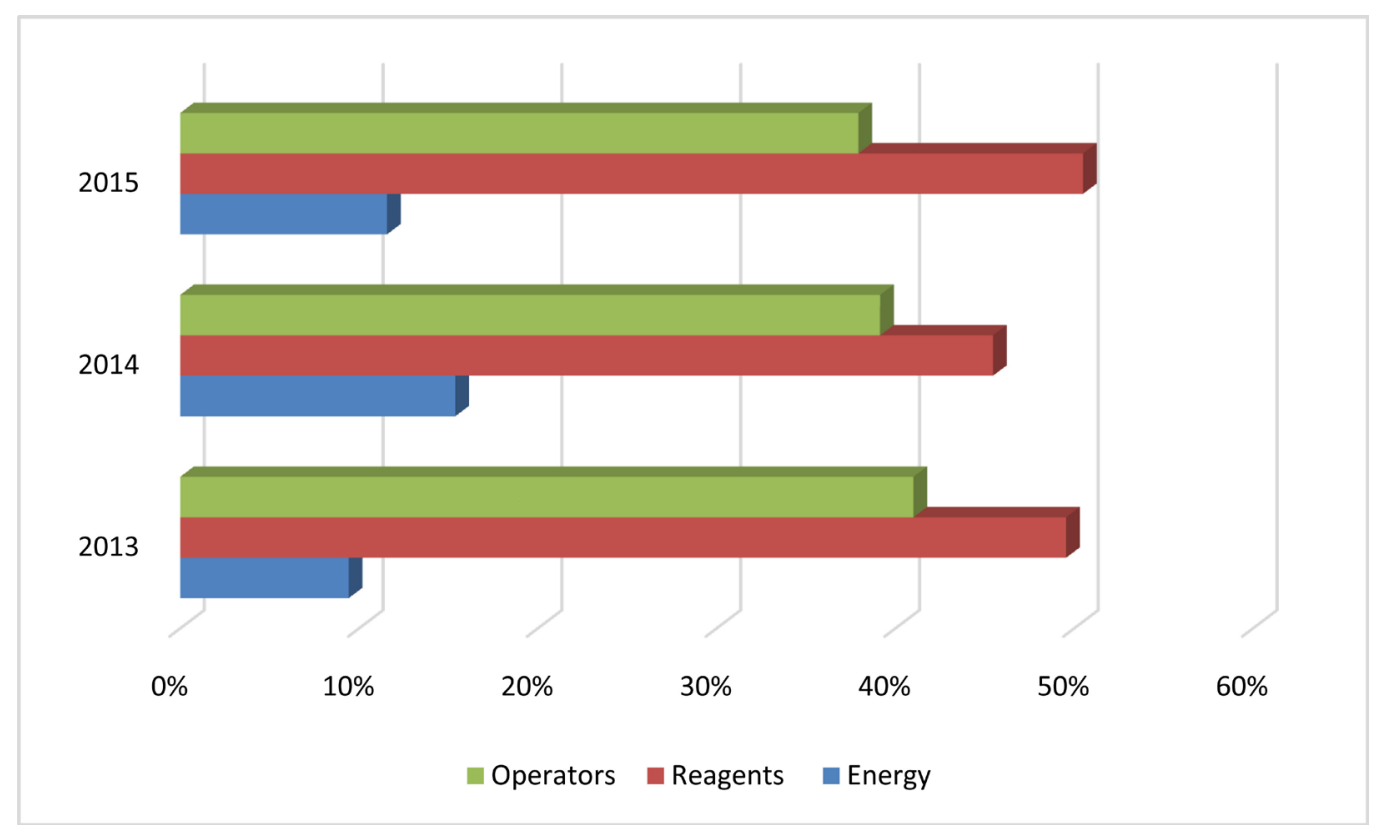

Figure 4. Operations expenses of the water treatment plant in 2013, 2014 and 2015 (ONEE, 2015).

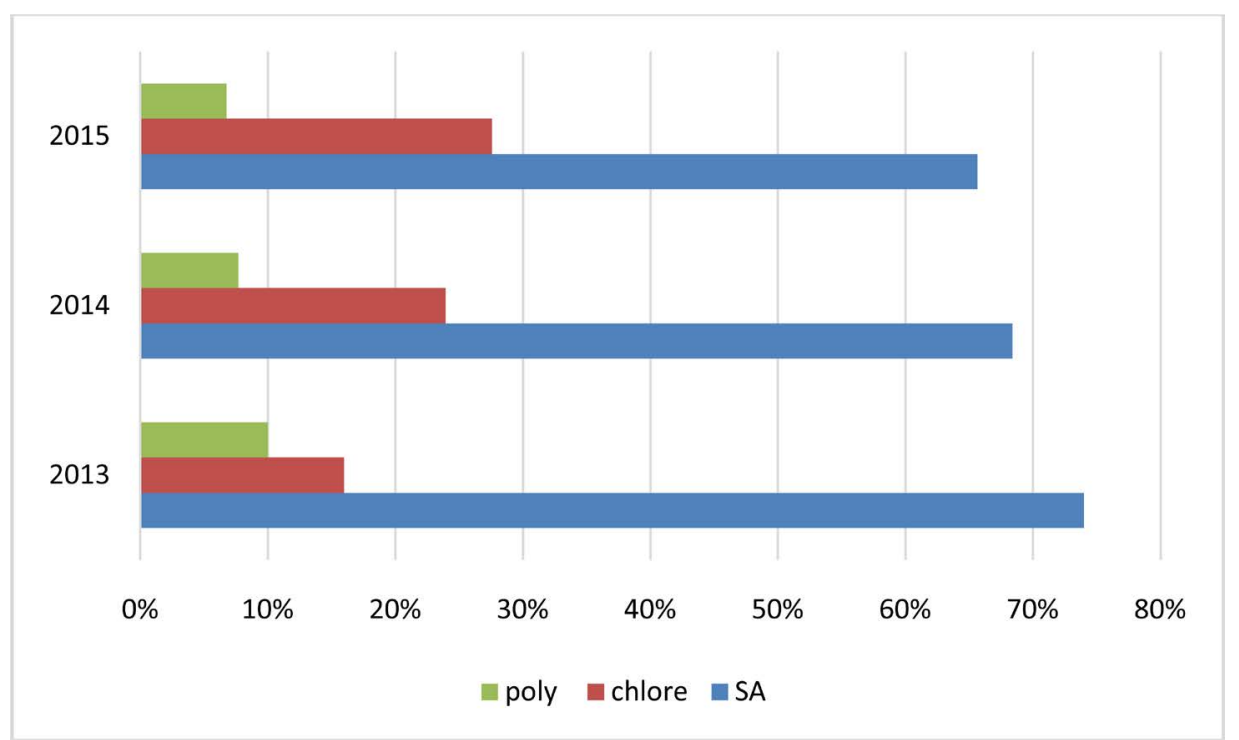

Figure 5. Percentage of chemicals expenses consumed by the water treatment plant in 2013, 2014 and 2015 (ONEE, 2015).

concerns the different steps of the process. The main goals are to:

- Achieve the chemical cost performance.

- Manage and control the energy consumption.

- Reduce the water wastes.

Many research and studies are performed in order to increase the water treatment plant performances. In this section, one aspect related to the optimization is treated which is the coagulant consumption.

\subsection{Coagulant and Coagulant Aid}

In the water treatment plant, colloidal particles are separated by means of a chemical coagulation process: consisting in the charge destabilization of the suspended particles by adding coagulant. The coagulant used is aluminum sulfate; it is the most widely used coagulant in Morocco as well as many other countries in the drinking 
water industry. It is mainly used because of its effectiveness, accessibility and low price. As a common practice, aluminum sulfate is applied according to the jars test results. The main difficulty is how to optimize the aluminum sulfate dosage related to raw water characteristics by using other cheaper products. Some attempts have been made to improve the effectiveness of the aluminum sulfate or to substitute this coagulant by another natural, available and cheaper. Finding of various coagulation processes have been reported in literature. Some of these include; studying the effect of using the bentonite on the coagulation in the treatment of low turbidity [1]. Also, Mukheled (2012) [2] used Date seeds and Pollen Sheath as coagulant to treat different levels of turbidity (75, 150 and 300 NTU). Eman et al. (2010) [3] tried Moringa Oleifera seed in the coagulation process to treat low turbid water in Malaysia. However, Aho et al. (2012) [4] highly recommended the use of this natural coagulant in the domestic turbid water purification in Nigeria. Other natural coagulants are proposed as an important alternative in the water treatment plant. The coagulants are from plant origin such as nirmali seed and maize [5], cassia angustifolia seed [6], mesquite bean and cactus latifaria [7], chestnut and acorn [8], Cocciniaindica fruit mucilage [9] and from different leguminous species [10]. Also, the Bhindi seed, Methi, Beheda, Guar seeds and Drum stick can be used as coagulant in 100 to 1200 NTU turbid water range with remarkable percentage removal from $70 \%$ to $93 \%$ [11]. In the other hand, Cocciniaindica, Strychnospotatorum and Cactus opuntia were used as natural coagulant and improved the quality of the filtered water [12]. Those natural products have coagulating activity in the treatment of turbid water and can be used as coagulant or as coagulant aid with other synthetic and industrial coagulants (aluminum sulfate...) in order to reduce the coagulant consumption in the water treatment plant [13].

\subsection{Coagulant Control and Monitoring}

As a common practice, aluminum sulfate is applied according to the jars test results. The problem is to determine the optimal dose of aluminum sulfate related to raw water characteristics. Both manual and automatic methods are used to predict optimum coagulant dose [14] [15]. Automatic method is ensured by streaming current detectors [16]. However, manual method is consisting to determine the quantity of the coagulant to apply experimentally and based on the jar test results. Jar test involves taking a raw water samples and applying different quantities of coagulant to each sample [15]. After a short period of time, each sample is assessed for water quality and the dosage that produces the optimal result used a set point. This operation should be repeated by the operators each time when the quality of raw water changes. The aluminum sulfate is the compound likely to be mathematically modeled and therefore its value can be estimated according to the data available in the treatment plant. The optimization of using the coagulant is very interesting approach because under dosing of coagulant can lead to poor quality drinking water while too much coagulant leads to many operating problems (less efficient filtration and sedimentation, $\mathrm{PH}$ ), healthy problems and can increase the cost of treated water.

Some attempts have been made to model the relationships between raw water quality characteristics and the optima coagulant dosage rate.

\section{Practical Methods of Water Treatment Plant Optimization}

\subsection{Understanding of the Water Treatment Process}

The understanding of the water treatment functioning is a very important step on the performances optimization program. A systematic gathering of information about plant performances are need such as:

- Data trending and analysis.

- Check plant design criteria against actual and the controlling operations to improve the plant performances.

- Track chemical dosing and use indicators.

- Field measurements and visual observation.

- Collaboration of operators (quality water operators, maintenance team and managing operator).

- Plant specific operating guidelines and procedures.

- Accuracy and control of the on-line measurement devices.

\subsection{The Aluminum Sulfate Consumption}

The sludge produced in the settling step of the treatment process is used not only to reduce the aluminum sulfate dose and the sludge volume but also in order to improve the water quality. 
A standard jar test apparatus equipped with six paddles rotating in a set of six beakers is used to simulate coagulation, flocculation and sedimentation processes. At the first, Control experiments for coagulation tests are performed in order to determine the optimal dose of the aluminum sulfate in normal conditions. The selected level of turbid water $(1 \mathrm{~L})$ is filled into the beakers and various doses in the range from 10 to $100 \mathrm{mg} / \mathrm{l}$ of sludge and the aluminum sulfate according to the results of the first jar test determining the optimal dose of the inorganic coagulant in normal conditions are separately added in the beakers and mixed rapidly $(300 \mathrm{rpm})$ for one minute. The mixing speed was then reduced to $40 \mathrm{rpm}$ for 20 minutes. Then the stirrer is turned off and the suspensions are allowed to settle for different periods of time ranging from 30 to 120 minutes under quiescent conditions. After each period of settling time, supernatant samples of each beaker in the jar test is withdrawn from located $10 \mathrm{~cm}$ below the water level and residual turbidity is measured.

Standard Jar test experiments were performed to determine the optimal dose of aluminum sulfate. A set of experiments were performed using jar test to investigate the optimal dose of sludge to add in order to improve the quality of water.

The sludge produced by the treatment plant and used with the aluminum sulfate improves the turbidity removal percentage and achieve good removal efficiencies. The maximum value of turbidity removal at turbidity of $10 \mathrm{NTU}$ is 98.41 corresponding to the optimum dose of sludge of $35 \mathrm{mg} / \mathrm{l}$.

A set of experiments is performed using the optimal sludge dose obtained from the experiments below (35 $\mathrm{mg} / \mathrm{l}$ ) while the aluminum sulfate was changed from 0 to $10 \mathrm{mg} / \mathrm{l}$. Figure 6 shows the effect of aluminum sulfate and sludge dose under various settling time on turbidity removal.

Table 4 gives the results of turbidity removal percentage using aluminum sulfate only, optimal dose of AS and sludge and the optimal dose of sludge and the proposed dose of AS.

The results show that the sludge used as coagulant aid with the aluminum sulfate improve not only the water

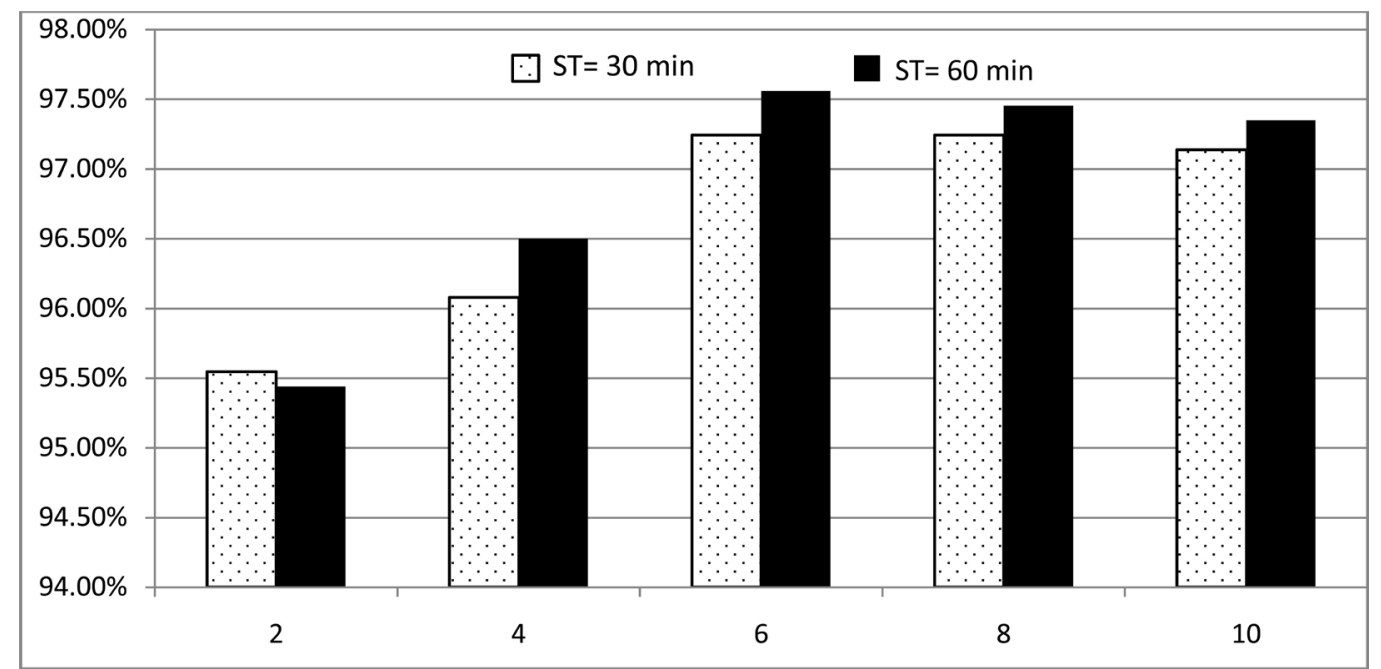

Figure 6. Effect of Aluminum sulfate doses $(\mathrm{mg} / \mathrm{l})$ and sludge dose $(35 \mathrm{mg} / \mathrm{l})$ under various settling time (ST) on turbidity removal percent $(\%)$.

Table 4. Turbidity removal percentage (\%) using AS and sludge at settling time of 60 minutes.

\begin{tabular}{cc} 
Initial turbidity & Turbidity $=\mathbf{1 0}$ NTU \\
\hline Optimal dose of Aluminum sulfate (mg/l) (1) & 10 \\
Optimal dose of sludge (mg/l) used within AS (2) & 10 \\
Dose of AS (mg/l) proposed to be used with optimal dose of sludge (3) & 35 \\
Turbidity removal percentage using only AS (1) & $96.71 \%$ \\
Turbidity removal percentage using AS and sludge as coagulant aid (1) $+(2)$ & $97.14 \%$ \\
Turbidity removal percentage using optimal dose of sludge and AS (2) $+(3)$ & $97.56 \%$ \\
\hline
\end{tabular}


quality produced by the treatment plant (turbidity removal percentage from $96.71 \%$ to $97.56 \%$ but also it can be used to reduce the aluminum sulfate dose in the coagulation process by $40 \%$.

\subsection{Chlorination}

The chlorine is the second chemical which impacts the cost of the treated water. The optimization of the consumption of this chemical can reduce the cost of the water produced by the water treatment plant. Some measures should be taken such as:

- On-line and laboratory instruments verification.

- Disinfection data handling and reporting.

- Verification of on-line chlorine residual analyzes.

- Verification of the performances of the on-line instruments with a grab sample measurement at least once every week.

- Respect of the manufacturer's instructions for instrument calibration.

- Completion of grab sample verification after changing reagents or doses or doing any other maintenance operations on the instrument.

- Incorporation of all manufacturer recommended instrument maintenance.

- Using a portable kit to verify performances of on-line instruments.

\subsection{Energy}

The energy consumed by the water treatment plant can be optimized by adopting many measures such as:

- Using of variables speed drives on pump motors.

- Lighting controls upgrade.

- The preventive maintenance of different equipment and motors.

- The replacement of existing pumps and motors by more efficient pumps and motors.

The implementation of such measures results in annual electric savings of more than $6 \%$ of the energy consumed by the water treatment plant.

\section{Conclusion}

This paper has presented some results concerning many practical methods used in the management of the water treatment plant, the use of sludge as coagulant aid with the aluminum sulfate in the water treatment plant. The sludge improves the quality of the produced water by increasing the coagulation efficiency and the aluminum sulfate dosage is decreased. The sludge volume is reduced and subsequently sludge management costs. The coagulation process is optimizing and this approach offers several significant economics and operational benefits such as it minimizes the aluminum dose required to $40 \%$, reduces the sludge volume produced by the treatment plant and decreases the residual turbidity of the water. These advantages are very important not only for process economy through reducing the cost of treatment but also in the management of the sludge volume. Therefore, it is reasonable to consider this approach to be applied in the treatment plant for water with similar turbidity level. Also, the chlorine and energy consumption can be reduced in order to optimize the water treatment plant performances.

\section{References}

[1] Shen, Y.H. (2005) Treatment of Low Turbidity Water by Sweep Coagulation Using Bentonite. Journal of Chemical Technology and Biotechnology, 80, 581-586. http://dx.doi.org/10.1002/jctb.1244

[2] Mukheled, A. (2012) A Novel Water Pretreatment Approach for Turbidity Removal Using Date Seeds and Pollen Sheath. Journal of Water Resource and Protection, 4, 79-92. http://dx.doi.org/10.4236/jwarp.2012.42010

[3] Eman, N.A., Suleyman, A.M., Hamzah, M.S., Zahangir, Md.A. and Salleh, M.R.M. (2010) Production of Natural Coagulant from Moringa oleifera Seed for Application in Treatment of Low Turbidity Water. Journal of Water Resource and Protection, 2, 259-266. http://dx.doi.org/10.4236/jwarp.2010.23030

[4] Aho, I.M. and Lagasi, J.E. (2012) A New Water Treatment System Using Moringa oleifera Seed. American Journal of Scietific and Industrial Research, 3, 487-492.

[5] Raghuwanshi, P.K., Mandloi, M., Sharma, A.J., Malviya, H.S. and Chaudhari, S. (2002) Improving Filtrate Quality 
Using Agrobased Materials as Coagulant Aids. Water Quality Research, 37, 745-756.

[6] Sanghi, R., Bhatttacharya, B. and Singh, V. (2002) Cassia An-Gustifolia Seed Gum as an Effective Natural Coagulant for Decolourisation of Dye Solutions. Green Chemistry, 4, 252-254. http://dx.doi.org/10.1039/b200067a

[7] Diaz, A., Rincon, N., Escorihuela, A., Fernandez, N., Chacin, E. and Forster, C.F. (1999) A Preliminary Evaluation of Turbidity Removal by Natural Coagulants Indigenous to Venezuela. Process Biochemistry, 35, 391-395. http://dx.doi.org/10.1016/S0032-9592(99)00085-0

[8] Šciban, M., Klašnja, M., Antov, M. and Škrbic, B. (2009) Removal of Water Turbidity by Natural Coagulants Obtained from Chestnut and Acorn. Bioresource Technology, 100, 6639-6643. http://dx.doi.org/10.1016/j.biortech.2009.06.047

[9] Patale, V. and Parikh, P. (2010) A Preliminary Study on Coccinia indica Fruit Mucilage Extract as Coagulant-Flocculent for Turbid Water Treatment. Journal of Pure and Applied Sciences, 18, 27-30.

[10] Šciban, M., Klašnja, M. and Stojimirovic, J. (2005) Investigation of Coagulation Activity of Natural Coagulants from Seeds of Different Leguminose Species. Acta Periodica Technologica, 36, 81-87.

[11] Amitkumar, A.G. and Farooq, I.C. (2015) Performance Evaluation of Some Natural Coagulants. International Journal of Civil and Structural Engineering, 3, 368-375.

[12] Nirmala Rani, C. and Jadhav, M.V. (2012) Enhancing Filtrate Quality of Turbid Water Incorporating Seeds of Strychnospotatorum, Pads of Cactus Opuntia and Mucilage Extracted from the Fruits of Coccinia indica as Coagulants. Journal of Environmental Research and Development, 7, 668-674.

[13] Farhaoui, M. and Derraz, M. (2016) Optimizing Coagulation Process by Using Sludge Produced in the Water Treatment Plant. Journal of Chemical and Pharmaceutical Research, 8, 749-756.

[14] Lind, C. (1994) Coagulation Control and Optimization: Part One. Public Works for October, 56-57.

[15] Lind, C. (1994) Coagulation Control and Optimization: Part Two. Public Works for October, 32-33.

[16] Liu, H.Y., Rong, Q.W., Xu, L.H. and Zhang, Y. (2013) Application of Automatic Control System in Water Plant in China. Journal of Convergence Information Technology (JCIT), 8, 243-250.

\section{Submit or recommend next manuscript to SCIRP and we will provide best service for you:}

Accepting pre-submission inquiries through Email, Facebook, Linkedin, Twitter, etc A wide selection of journals (inclusive of 9 subjects, more than 200 journals)

Providing a 24-hour high-quality service

User-friendly online submission system

Fair and swift peer-review system

Efficient typesetting and proofreading procedure

Display of the result of downloads and visits, as well as the number of cited articles

Maximum dissemination of your research work

Submit your manuscript at: http://papersubmission.scirp.org/ 